\title{
Ecological Influences on Tuber Aestivum Distribution in the Subcarpathian Region of Transylvania
}

\author{
Horea PĂCURAR ${ }^{1}$, Marcel DÎRJA ${ }^{1}$, Ioan PĂCURAR ${ }^{1}$, Sanda ROȘCA ${ }^{* 2}$, Ștefan BILAȘCO ${ }^{2,3}$, Cornel \\ NEGRUȘIER ${ }^{1}$ \\ ${ }^{1}$ Department of Soil Sciences and Technical Sciences, University of Agricultural Sciences and Veterinary Medicine Cluj-Napoca, \\ Romania \\ ${ }^{2}$ Department of Physical and Technical Geography, Faculty of Geography, Babeș Bolyai University, Romania. \\ ${ }^{3}$ Romanian Academy Cluj-Napoca Subsidiary, Geography Section, Romania. \\ *corresponding author: sanda_rosca@yahoo.com
}

Bulletin UASVM series Agriculture 76(2) / 2019

Print ISSN 1843-5246; Electronic ISSN 1843-5386

DOI:10.15835/buasvmcn-agr: 2019.0036

\begin{abstract}
:
The aim of this research was to identify the ecological factors which have influences on distribution, development and habitat suitability of the summer truffle (Tuber aestivum) in the Sub-Carpathian region of Transylvania. The ecological factors such as average annual temperature $\left({ }^{\circ} \mathrm{C}\right)$, average annual precipitation (mm/ year), the length of the bioactive period (months), land slope (grade), slope orientation, soil $\mathrm{pH}$ and its compaction level were analyzed having specific influences on forest vegetation development in Sub-Carpathian hills, and in the same time on the possibility of symbiosis existence between the trees and summer truffle. The most favorable regions from the Sub-Carpathians of Transylvania for summer truffle growth proved to be Dealurile Năsăudului and Homoroadelor Sub-Carpathians followed by Muscelele Năsăudului and hills of Bistrița, where the average annual temperature is between $6,8-11^{\circ} \mathrm{C}$ with an average annual precipitation of $900 \mathrm{~mm} /$ year, a 3-6 months long bioactive period and high humus content of the soil.
\end{abstract}

Keywords: Summer truffle, symbiosis, mapping, ecology

\section{Introduction and study area}

Tuber aestivum Vittad. generally known as black summer truffle is a fungus belonging to the Tuberaceae family within the Tuber genus. The shape and size of the underground fruits are very variable. The fruiting bodies are formed from groups resulting in an irregular bumpy shape and a warty look and texture. Their diameters can vary from 2 to 10 centimeters (Figure 1.).

Black summer truffle is a mycorrhizal fungus which grows in symbiosis with various host tree species, such as oak, beech, and hazel. This relationship is characterized by the transfer of nutrients beneficial for both organisms (the tree provides vitamins and glucose necessary for growth and fruiting for the truffle contributing also to the color, taste and smell, while the truffle provides indispensable nutrients for the tree such as potassium, phosphorus, calcium nitrogen and iron).

The best black truffles undoubtedly come from Perigord, France but white truffles, especially the ones from around Alba, Italy are the most desirable and higher-priced than other truffles. Black truffles grow spontaneously in many parts of Europe such as France, Spain, Italy, Serbia, Romania, Croatia, Australia and they were adapted also to the climatic conditions of New Zealand, Chile, Argentina and Canada (Racolța, 2015).

T. aestivum Vittad. establishes symbiosis with trees belonging to the Castanea, Cistus, Corylus, Fagus, Ostrya, Tilia, Picea, Carya, Pinus and Quercus genus (Ceruti et al., 2003, Wang et al., 2008, Wedén et al., 2009, Chevalier 2009, Benucci et al., 2012; 
Stobbe et al., 2013). As reported by Gryndler et al. (2014) Tuber aestivum can establish symbiosis also with herbaceeus species such as G. urbanum or Hedera helix as a non-host species for truffles.

Not only host trees, but also a series of insects can be good indicators for the occurrence of truffles. Among these, the most remarkable ones are: Colenis immunda (round fungus beetle), Suillia gigantea (truffle fly) and Leiodes cinnamomea (truffle-beetle) (Figure 1.).

The presence of the insects in some areas, clearly indicate the place where the mature truffles can be found. These insects are attracted by the specific smell of the truffles and are considered pests can cause extensive damage to truffles. For Suillia gigantea, truffles are hosts for the larvae providing proper conditions for the appearance of a new generation.

Different studies show that in the vicinity of the colonized trees by Tuber aestivum the density of the herbaceous species is much lower due to the allelopathic substances that this fungus releases inhibiting germination and impeding plant life nearby (Streiblova et al., 2012). Knowing about this dependency and mutuality it is a must for those who would like to localize this precious fungus species and to improve its productivity (De Miguel et al., 2014).

As an alternative for the exiting truffle species in the spontaneous flora, where the climatic and growth conditions are suitable for them, in their natural habitats, micchorized spears are collected, sold and used to establish new truffle cultures.

In Romania, T. aestivum Vittad. is the most successfully adapted species to the climatic and soil conditions of the country, and it is grown by an increasing number of people who are establishing summer truffle cultures using Corylus avellana, Quercus robur and Carpinus betulus as host trees (Racolța, 2015).

Different studies have been made to investigate the territories of Sweden and Morocco where truffles grow.

The most suitable areas were found to be characterized by an average annual temperature ranging from 6,8 to $11,5^{\circ} \mathrm{C}$, an average annual precipitation from 400 to $1500 \mathrm{~mm}$ /year and soils with a pH varying from 5,9-9,4 (Bencivenga et al., 1995, Stobbe et al., 2012).

The aim of this research was to identify the most suitable areas for summer truffle cultures in the Sub-Carpathian region of Transylvania from
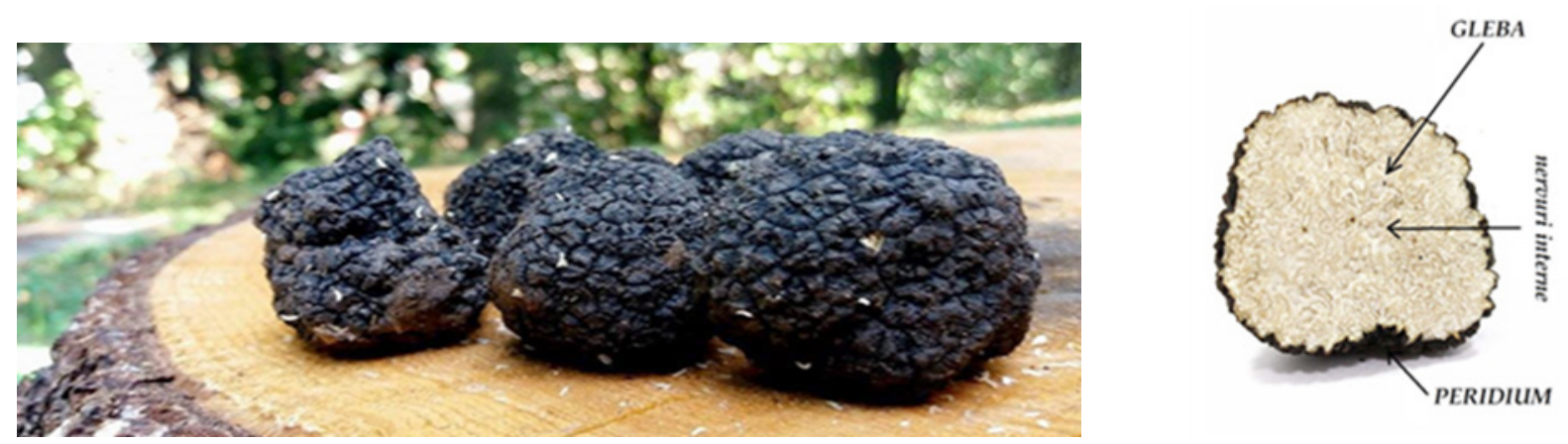

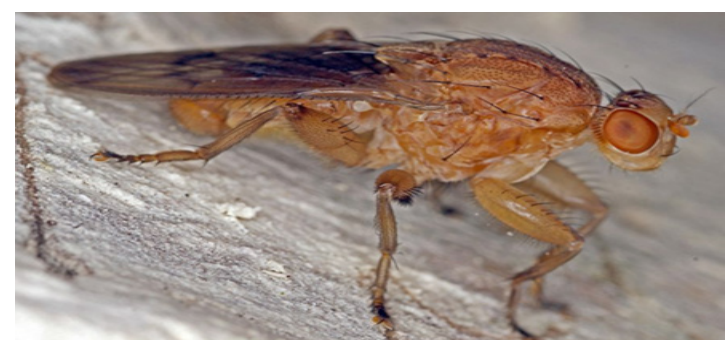

Suillia gigantea

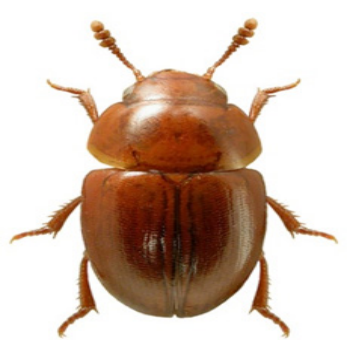

Leiodes cinnamomea

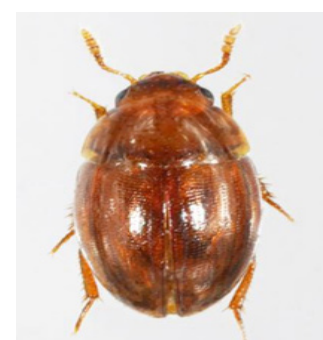

Colenis immunda

Figure 1. The structure of Tuber aestivum and the most common pests 


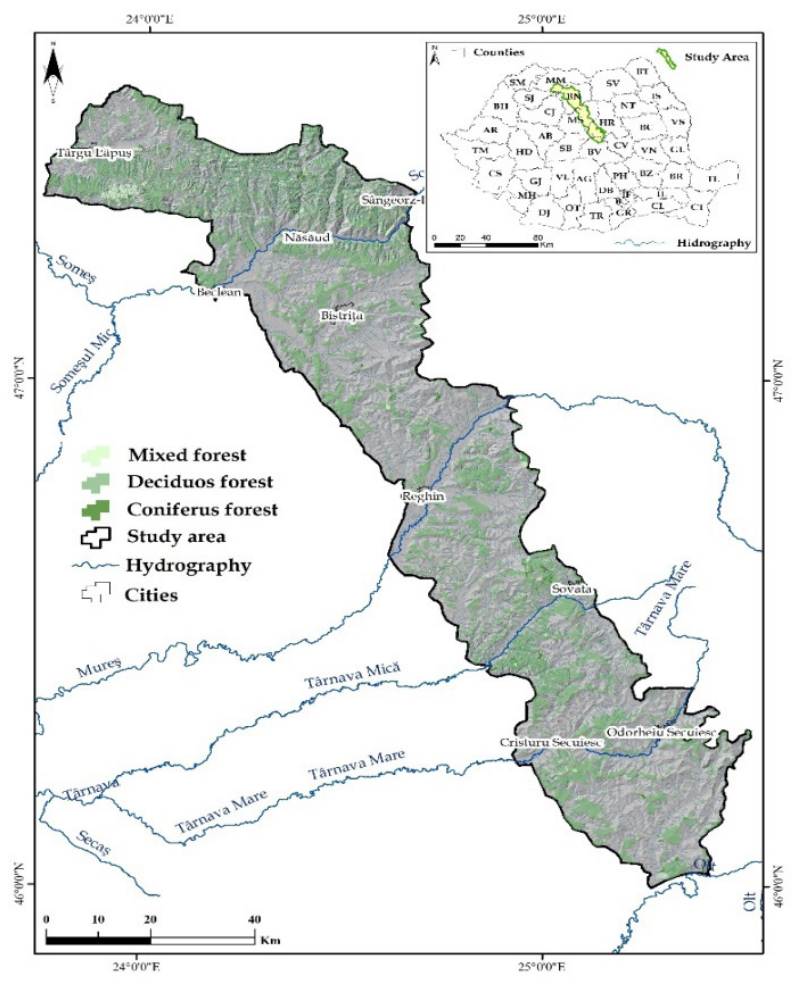

Figure 2. Geographical position of the study area and the distribution of forest covers according to Corine Landcover's reports (2012)

Romania based on the environmental conditions and their influences on the species growth and development. The study area covers $5645.36 \mathrm{~km}^{2}$ and is considered the transition area between the Eastern-Carpathians and Transylvanian hollow, including valleys and hills which altitude range from 246,5 to $1187.1 \mathrm{~m}$.

The area covered by forests has 161898 hectares representing $28,67 \%$ of the total area under study. Among the forests the most favorable conditions for summer truffle growth were found to be in the Sub-Carpathian hillsides with a deciduous forest cover (155830 hectares) followed by areas with mixed forest covers (4212,14 hectares) and the other 1855.5 hectares with conifer forest found at higher altitudes reaching the limits of the mountainous regions (Figure 2.).

\section{Materials and Methods}

In order to identify land favorability and environmental conditions for summer truffle growth in the studied area, a series of limiting factors with high impact were analyzed which can determine the distribution of the species. The factors analyzed were climatic parameters such as annual average temperature and precipitation, descriptive parameters of the relief (altitude, slope, site exposure) and soil properties especially $\mathrm{pH}$ and soil compactness (Figure 3.). All these parameters were recorded by using geographic information systems software which allows the interpolation of the values of all recorded parameters providing such way a continuous

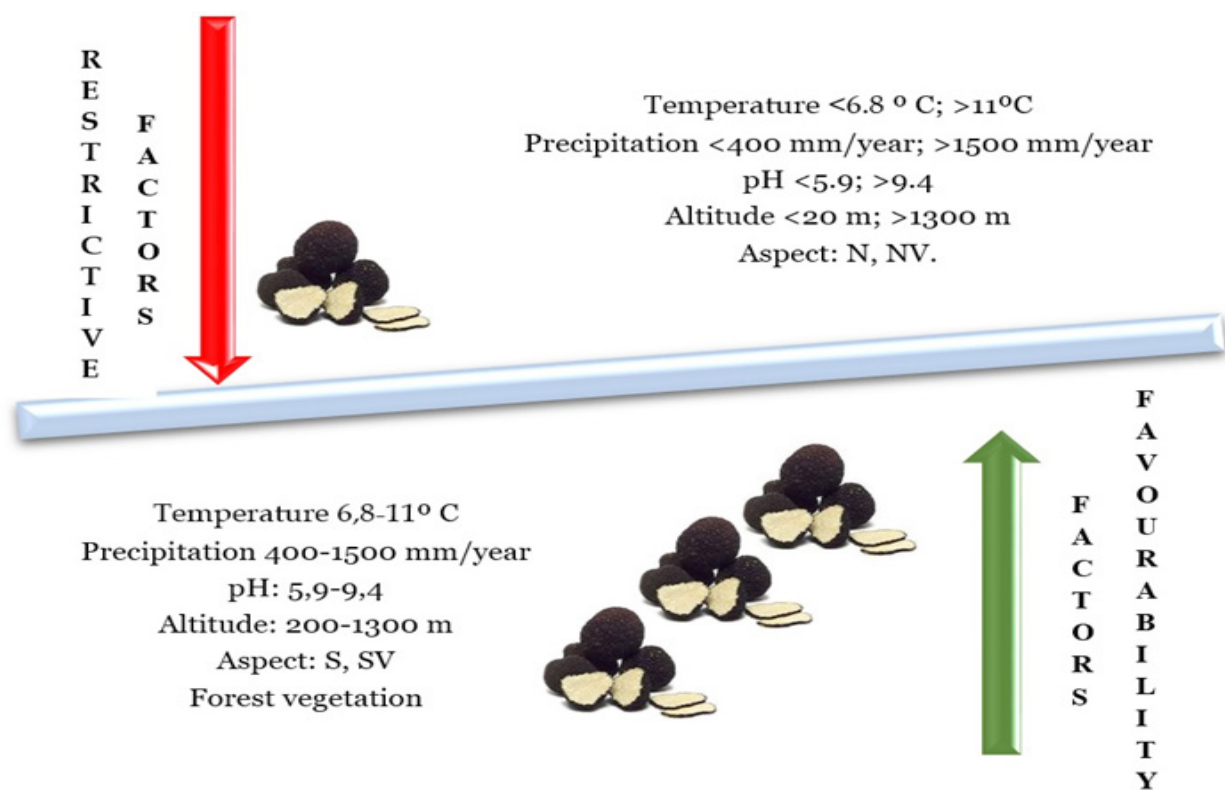

Figure 3. Favorable and limiting factors for T. aestivum Vittad. growth and development 
grid for the investigated area (Roșca et al., 2017, Mândru et al., 2017).

By using ArcMap software and spatial analysis was possible to identify (choosing the options select, identify and overlay) areas which are suitable for T. aestivum Vittad. growth and development, but also to exclude regions where the environmental conditions could be restrictive for summer truffle cultivation in the studied area. All the data that have been registered were analyzed and classified as follow: favorable areas for T. aestivum Vittad. growth were coded as "1", while the areas with low or no favorability for summer truffle growth were coded as " 0 ".

The equation used in Raster Calculator is shown below:

"temp" * "precip" * "pH" * "altitude" * "aspect" * "landuse" * "slope" * "bioactive_period"

The final raster as a result of the analysis indicates both favorable and restricted areas for T. aestivum Vittad. cultivation in the area under study. The results obtained could be statistically analyzed to reveal significant differences between the favorable and restricted area extensions at different levels (relief subunits or territorial administration) of the studied area (Roșca, 2015, Moldovan et al., 2016, Bilașco et al., 2016).

\section{Results and Discussion}

The main characteristics of the relief that may have greatinfluences on summer truffle growth and development are represented, notably by altitude and site exposure but also other characteristics such as slope, fragmentation density or eroded areas and flow accumulation that have a great impact on the existing wooden vegetation.

Regarding the altitude of the relief, black summer truffles were detected at various altitudes varying from 200 - 1300 m, by Racolța (2015), altitudes that label the entire Sub-Carpathian region with high favorability for T. aestivum Vittad. culture.

Site exposure is the second most important indicator that has considerable influence on summer truffle development; the most favorable areas detected had southern or south-eastern exposures. Therefore, it can be claimed that sunny sites are more favorable for summer truffle cultures in comparison with other sites which do not fall in the category of restricted areas but have low favorability due to the effects of multiple factors.

The site exposures are highly variable across the study area but their distribution percentages are very similar: $22.6 \%$ being represented by shady slopes $\left(1280,7 \mathrm{~km}^{2}\right), 24,1 \%$ penumbra on the eastern or north-western exposures $(1372,3$ $\mathrm{km}^{2}$ ), and $27,2 \%$ in full sun with southern or south-western exposures $\left(1541,2 \mathrm{~km}^{2}\right)$ and the remaining $24,9 \%$ being situated in partial sun having western or south-eastern exposures $\left(1444,7 \mathrm{~km}^{2}\right)$. In the forest covers with southern, south-western, western, eastern, south-eastern, northern and north-western exposures summer truffle cultures were found only in a few places, while in the north-western exposures were no trace of any truffle culture due to unfavorable conditions from these areas.

Among the climatic factors from the SubCarpathian regions of Transylvania on land suitability that influence summer truffle growth, average annual temperature, average annual precipitation, annual frequency and distribution of precipitation and late autumn frosts worth to be mentioned.

Regarding the average annual temperature, this varies between $5,09-10,07^{\circ} \mathrm{C}$ in the studied area, the highest temperatures being recorded in Somes and Mures Valleys and also in the hollow of Lăpuș (Figure 5.), while the lowest temperatures being recorded in the high hills situated near the border of the mountanous layers, predominantly in the eastern side of the Sub-Carpathian regions of Transylvania. These territories are characterized by high amount of precipitation fallen in a year reaching over $900 \mathrm{~mm}$, providing a sufficient quantity of water for forest trees.

Considering the needs of summer truffle, they can successfully grow and develop in regions with annual average temperatures between 6,8$11^{\circ} \mathrm{C}$, namely in the most part of the studied area excepting higher altitudes (over $900 \mathrm{~m}$ ) where the average annual temperature can drop below $6^{\circ} \mathrm{C}$. The amount of average annual precipitation from the Sub-Carpathian region of Transylvania makes this region favorable for black summer truffle growth.

Besides, the duration of the vegetation period has a great influence on tree species development in the study area, each of them having an optimal 

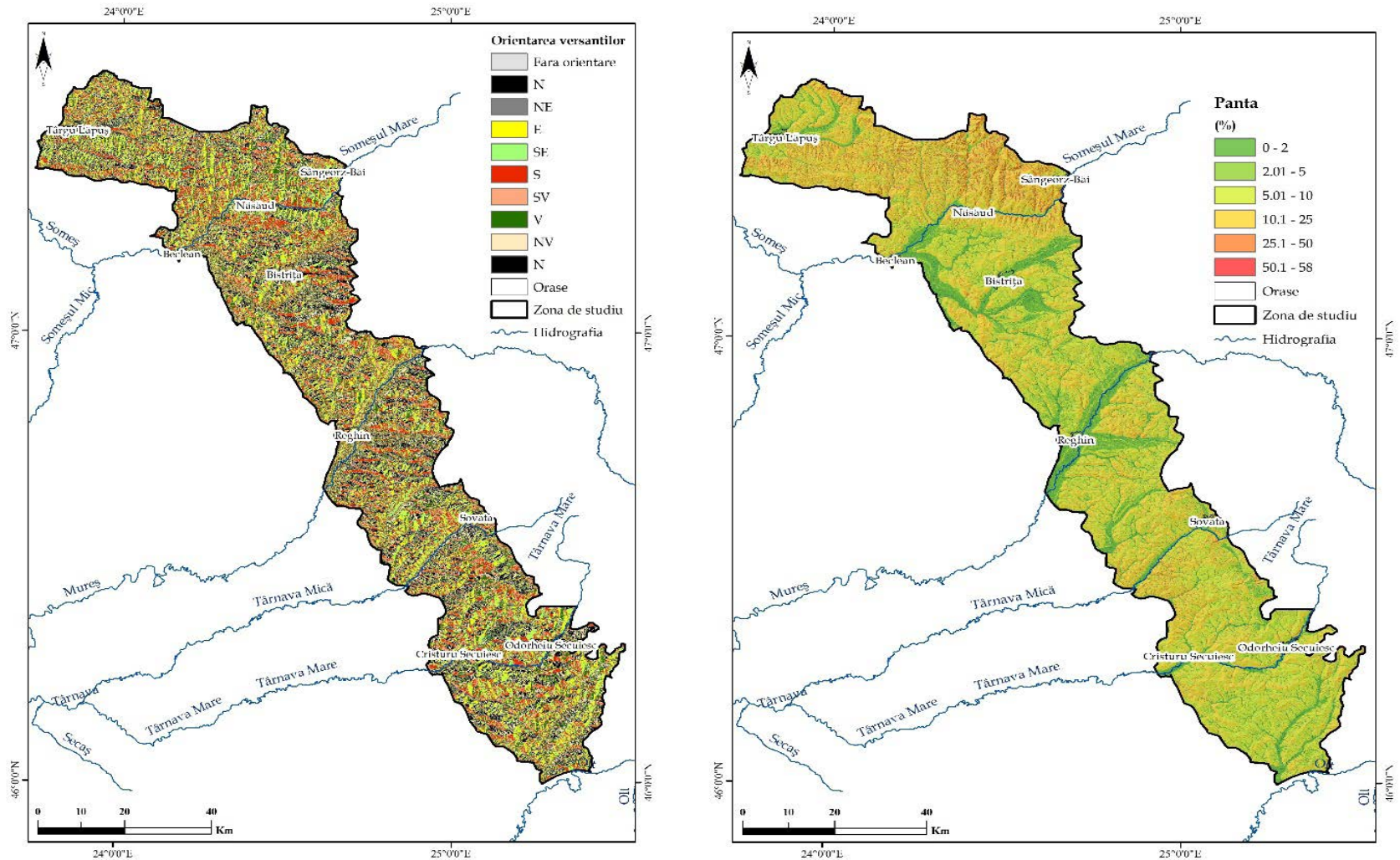

Figure 4. Slope maps (left) and site exposure(right) from the Sub-Carpathian region of Transylvania
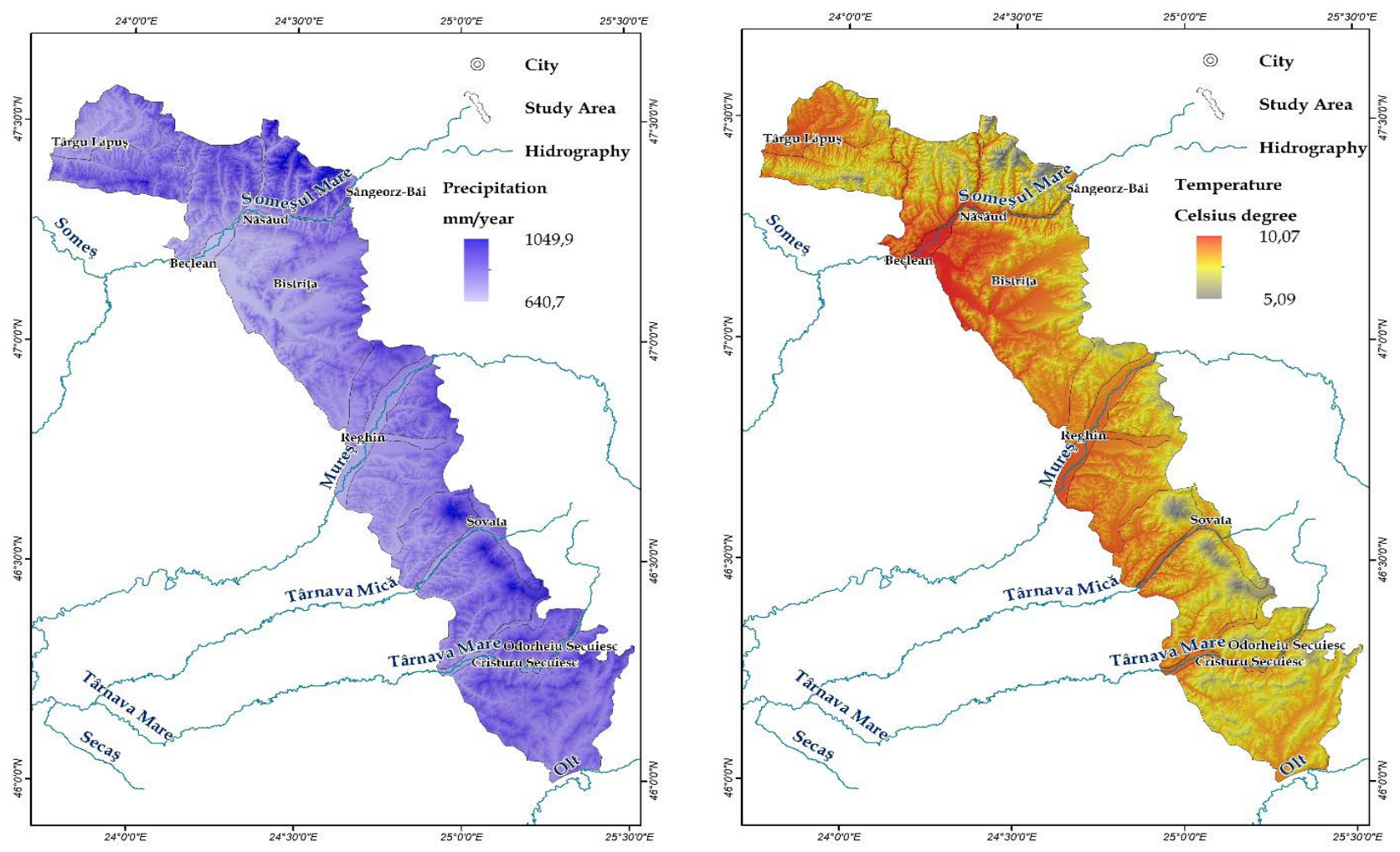

Figure 5. The map of average annual temperature (left) and precipitation (right) 

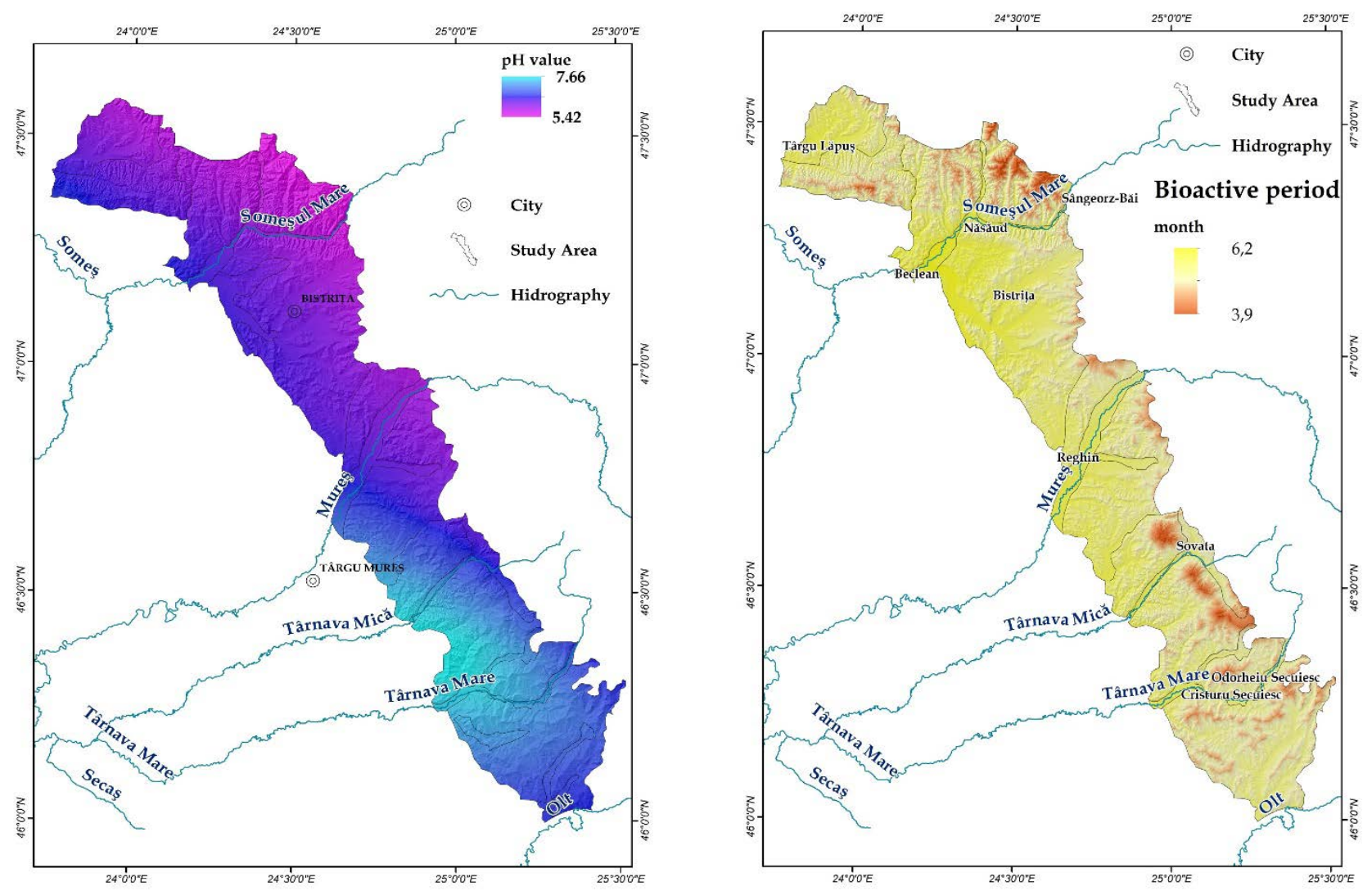

Figure 6. The length of the vegetation period (left) and soil $\mathrm{pH}$ in the Sub-Carpathians of Transylvania (right)

interval for growth and reproduction (Stănescu, 1979).

The length of the vegetation season in the Sub-Carpathians of Transylvania is three to six months including a period when the average annual temperature is above $10^{\circ} \mathrm{C}$ (Figure 6).

Among the limiting factors for summer truffle growth, high amount of precipitation is one of them, that can reduce truffle production leading to rot or the reverse, long term drought during summer (June, July and August) can stop truffle growth and considerably reduce truffle production and its quality. In this case the soil has a very important role through its water storage capacity, soil water availability and its depth, which can serve as a reservoir for summer truffle growth in harsh conditions.

Taking into consideration the fact that summer truffles are hypogeous fungi belonging to the Pezizales (Ascomycota) being a large group of symbiotic fungi with underground growth, it is obvious that their ecological needs are very high against the physicochemical and mechanical properties of the soil.

Unconventionally, these characteristics are recommended to be analyzed together with other determining factors of the climate such as temperature, the amount of precipitation, slope etc. that can define together the favorability level or the restriction level of the site for summer truffle growth and development.

A land becomes restrictive for summer truffle growth when the soil is super-saturated or the essential elements for summer truffle and host plant nutrition are missing and no symbiotic relationships can be established between the species.

In general, summer truffles can successfully grow in calcareous, clayey, well-drained soils with a high water content and a high level of minerals such as nitrogen, phosphorous, potassium and calcium carbonate.

Another important characteristic that has to be analyzed in order to define the favorability 


\section{ARTICLE IN PRESS}
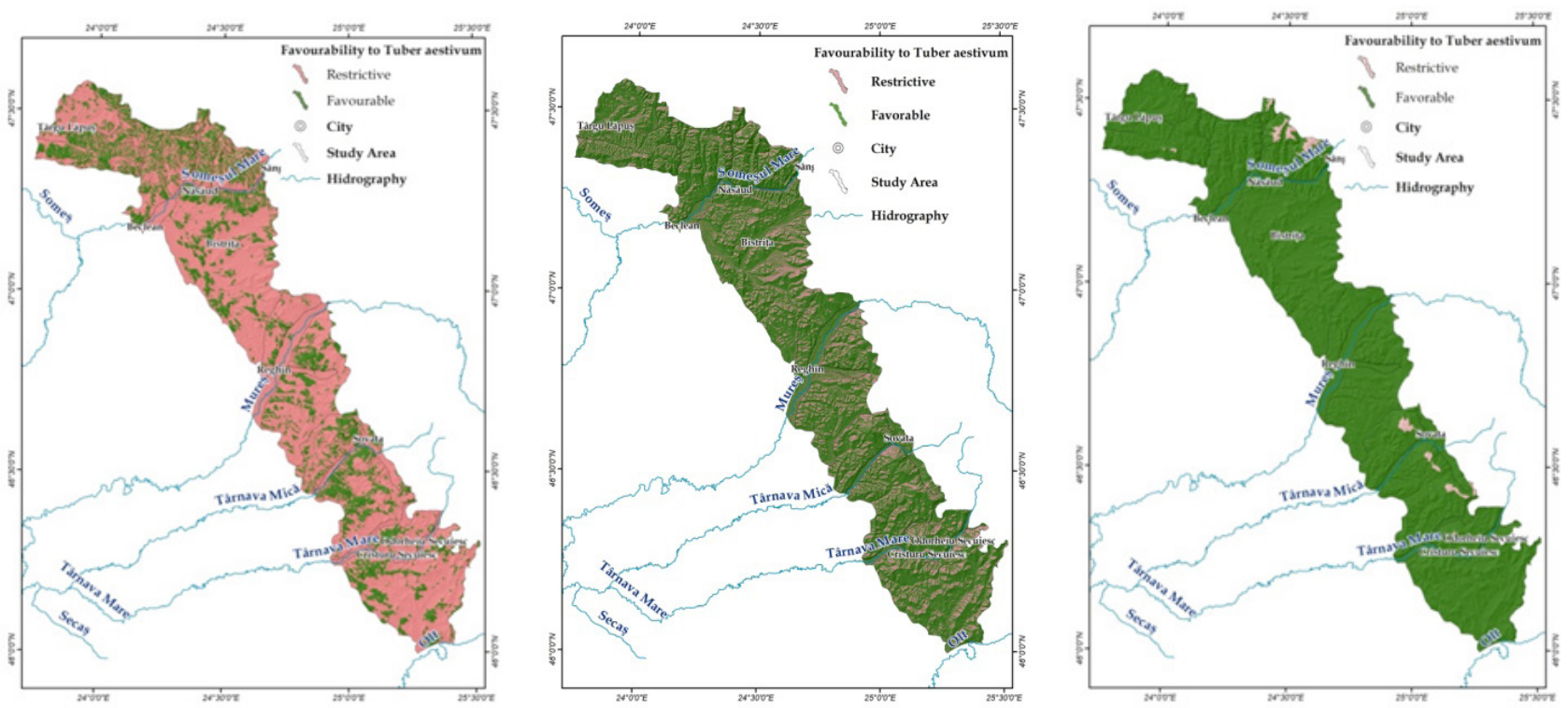

Figure 7. Land favorability for T. aestivum Vittad. given by site exposure (left), annual average temperature (middle) and land use (right)

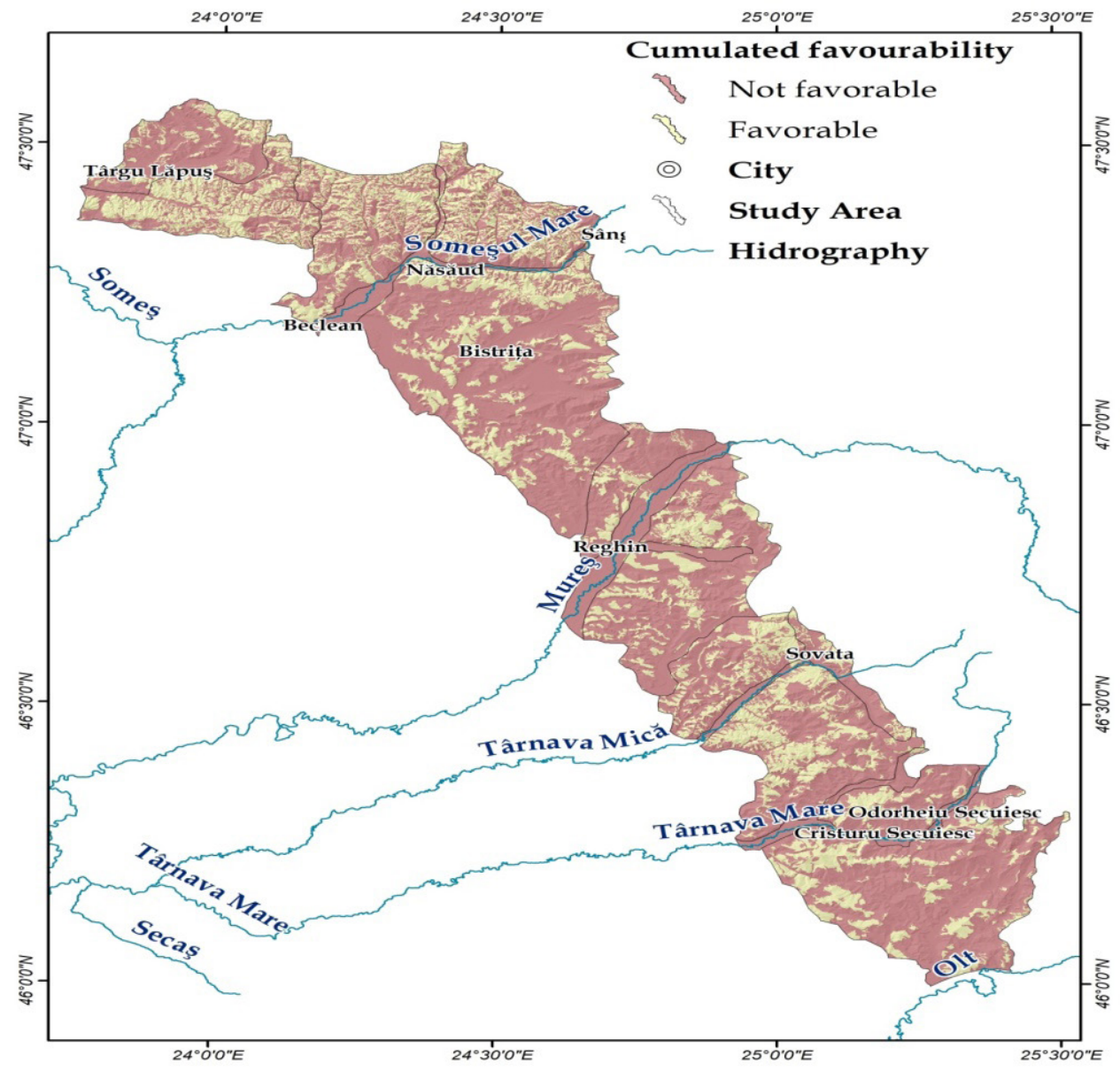

Figure 8. Map of land favorability for T. aestivum Vittad. 
level of the land for summer truffle growth is the $\mathrm{pH}$ of the soil, which has to fall between 6-9 to be considered suitable, but the optimal $\mathrm{pH}$ for summer truffle growth is 8.5. Regarding the summer truffle requirements against the organic matter of the soil, it was previously reported (Racolța, 2015) that summer truffles provide better yield when they grow on soils rich in organic matter and minerals and scarified all year long.

Among the limiting factors for T. aestivum Vittad. growth in the Sub-Carpathian region of Transylvania, the average annual temperature below $6,8^{\circ} \mathrm{C}$, the northern and north-western exposures and areas without forest covers have to be mentioned (Figure 7.).

The results of this research consist of a map of cumulative land favorability for T. aestivum Vittad. generated by geographic information system (Figure 8.) based on spatial distribution analyses.

In this map, as shown in (Figure 8.) it can be observed that the hills of Năsăud and Homoroadelor from the Sub-Carpathians are ranked with high land favorability level for $T$. aestivum Vittad. cultivation.

In contrast, on the opposite pole of the studied area where the forest covers are smaller as well as the high hill region where the climatic factors are restrictive, the land favorability is much more reduced for summer truffle cultivation.

In order to extend the fields for $\mathrm{T}$. aestivum Vittad. cultivation in the studied area, Muscelele Năsăudului covering $324,7 \mathrm{~km} 2$ would be the most suitable followed by Dealurile Bistriței with 291,5 km2 and Subcarpații Homoroadelor cu 200,7 km2 (Tab. 1).

\section{Conclusion}

Summer truffles can easily adapt to the ecological conditions of Romania, reason why more and more people are interested in their cultivation. Due to the unique and delicate aroma that summer truffles have in comparison to other species from the Romanian flora, and their high price, it is very important to know the ecological factors that considerably influences land favorability for summer truffle cultivation in Romania.

In this study, all the factors regarding relief (altitude, slope, site exposure), climate (average annual temperature, annual average precipitation) and soil characteristics $(\mathrm{pH}$, soil type, structure etc.) were analyzed to establish land favorability classes for summer truffle growth and production.

Table. 1. Relief unit rankings of land favorability

\begin{tabular}{lcccc}
\hline \multirow{2}{*}{ Relief } & \multicolumn{2}{c}{ Not favorable } & \multicolumn{2}{c}{ Favorable } \\
\cline { 2 - 5 } & Area (km2) & \% & Area (km2) & \% \\
\hline Muscelele Năsăudului & 408,1 & 55,7 & 324,7 & 44,3 \\
\hline Culmea Brezei & 169,1 & 47,5 & 187,0 & 52,5 \\
\hline Depresiunea Lăpuș & 215,2 & 78,1 & 60,4 & 21,9 \\
\hline Dealurile Mureșului & 599,9 & 75,4 & 195,8 & 24,6 \\
\hline Depresiunea Sovata & 63,1 & 75,6 & 20,4 & 24,4 \\
\hline Subcarpații Homoroadelor & 639,0 & 76,1 & 200,7 & 23,9 \\
\hline Dl. Bistritei & 937,7 & 76,3 & 291,5 & 23,7 \\
\hline Culuarul Târnavelor & 111,2 & 95,5 & 5,3 & 4,5 \\
\hline Culuarul Someșului & 79,9 & 94,2 & 4,9 & 5,8 \\
\hline Culuarul Mureșului & 180,3 & 97,2 & 5,1 & 2,8 \\
\hline
\end{tabular}


Therefore, a spatial analysis has been carried out to be able to rank the whole study area into favorability classes and restriction areas for summer truffle production. The areas with northern or north-western exposures where the average annual temperature is $6.8^{\circ} \mathrm{C}$, proved to be unsuitable for summer truffle cultivation. There were also found other areas where the ecological factors are beneficial for summer truffle growth but the forest cover is missing. Due to the lack of the host plants the occurrence of summer truffle in these areas is impossible.

The model map obtained based on the eight ecological factors analyzed, provides a clear classification of land favorability for summer truffle growth in the Sub-Carpathian region of Transylvania.

\section{References}

1. Bencivenga M, Di Massimo G, Donnini D, Tanfulli M (1995). Confronto tra la vegetazione delle tartufaie di Tuber aestivum Vitt., T. magnatum Pico e T. melanosporum Vitt. nell'Italia centrale. Micol. Ital, 24: 87-95.

2. Benucci GMN, Bonito G, Baciarelli LF, Bencivenga M (2012). Mycorrhization of Pecan trees (Carya illinoinensis) with commercial truffle species: Tuber aestivum Vittad. and Tuber borchii Vittad. Mycorrhiza, 22: 383-392.

3. Bilaşco S, Roşca S, Păcurar I, Moldovan N, Bot A, Negrușier C, Sestraș P, Bondrea N, Naș S, (2016). Identification of Land Suitability for Agricultural Use by Applying Morphometric and Risk Parameters Based on GIS Spatial Analysis. Not Bot Horti Agrobo. Doi:10.15835/nbha44110289.

4. Ceruti A, Fontana A, Nosenzo C (2003). The specie europee del genere Tuber. Una revision storica (p p.467). Torino.

5. Chevalier G ( 2009). The truffle of Europe (Tuber aestivum Vitt.): ecology and possibility of cultivation. First Conference on the European Truffle Tuber aestivum/ uncinatum.Vienna.

6. De Miguel AM, AguedaB, Sanchez S, Parlade J (2014). Ectomycorrhizal fungus diversity and community structure with natural and cultivated truffle hosts: applying lessons learned to future truffle culture. Mycorrhiza, 24: 5-18.

7. Gryndler M, Černá L, Bukovská P, Hrš-elová H, Jansa J, (2014). Tuber aestivum association with non-host root., Mycorrhiza. Doi:10.1007/s00572-014-0580-9.
8. Hall IR, Brown GT, Zambonelli A (2007). Taming the truffle. Portland, Timber Press.

9. Hall IR, Yun W, Amicucci A (2003) Cultivation of edible ectomycorrhizal mushrooms. Trends Biotechnol, 21: 433-438.

10. Mîndru M, Păcurar I, Roșca S, Bilașco Ș (2017).Forest favorability in Mociar Forest, Romania. ProEnvironment, 10: $75-85$.

11. Moldovan N, Păcurar I, Roșca S, Bilașco Ș (2016). Land favorability to crops in Intercommunity Association For Development Alba Iulia. Geographia Napocensis X (1): 7584.

12. Racolța N ( 2015). Ghidul culegătorilor de trufe, Zalău Technoprint, (Chapter 2).

13. Roșca S (2015). Bazinul Nirajului Studiu de Geomorfologie Aplicată, Cluj Napoca Risoprint, (Chapter 4).

14. Roșca S, Bilașco Ș, Păcurar I, Colniță D, Fodorean I, Vescan I, Petrea D, Păcurar H, (2017) Quantitative evaluation of forest favourability using GIS database in a hill area in the Transylvania Depression, Romania, Geomatics, Natural Hazards And Risk. Doi:10.1080/19475705.2017.140101 2.

15. Stănescu V (1979). Dendrologie, București Editura Didactică și Pedagogică.

16. Stobbe U, Büntgen U, Sproll L, Tegel W, Egli S, Fink S (2012). Spatial distribution and ecological variation of re-discovered German truffle habitats. Fungal Ecol, 5: 91199.

17. Stobbe U, Büntgen U, Sproll L, Tegel W, Egli S, Fink S (2012). Spatial distribution and ecological variation of rediscovered German truffle habitats. Fungal Ecol, 5: 591599.

18. Streiblova E, Gryndlerova H, Gryndler M (2012) Truffle brûle: an efficient fungal life strategy. Fems Microbiol. Ecol. 80: 1-8.

19. Wang G, Li Y, Li D, Tang Y (2008). Determination of 5 alphaandrost-16-en-3 alpha-ol in truffle fermentation broth by solid-phase extraction coupled with gas chromatographyflame ionization detector/electron impact mass spectrometry. Journal of Chromatography B-Analytical Technologies in the Biomedical and Life Sciences, 870: 209-215.

20. Wedén C, Pettersson L, Danell E (2009). Truffle cultivation in Sweden: Results from Quercus robur and Corylus avellana field trials on the island of Gotland. Scandinavian Journal of Forest Research, 24: 37-53. 